\title{
“How Could a Mother Do That to Her Children?": Filicide and Maternal Ambivalence in Croatian Media and Online Discourse
}

\author{
Barbara Pleić Tomić ${ }^{1 *}$
}

Published: September 10, 2019

\begin{abstract}
Four filicide cases that occurred in Croatia in 2014-17 received wide national media coverage and caused strong public reactions. In each case, the mother of the child(ren) was the perpetrator.

This paper will analyse different representations of motherhood, the contradictions and inconsistencies between motherhood as an idea and ideology and everyday maternal practices and behaviours, with special attention being paid to the concept of maternal ambivalence and the expression of violent impulses towards children. Furthermore, the research will also paint a broader picture of the ideology and representations of motherhood. This will include the prescriptive norms of the ideal motherhood present in the public discourse, encompassing the official expert discourse of parenting, as well as the 'private' discourse of internet forums covering the issues of parenting and child rearing.
\end{abstract}

The purpose of this analysis is to show how the public profile of the mothers who committed filicide is created on the dichotomies of the ideal, self-abnegating mother and the monstrous 'non-mother' (Croatian: nemajka), with all of its horrifying, dehumanising characteristics, and how this influences the general construct of maternity, motherhood and the figure of the ideal mother in the patriarchal family and social structures.

Keywords: filicide, intensive motherhood, media, maternal ambivalence

\section{INTRODUCTION}

On May 72014 I. P. R. (38) jumped from the 11th floor of her apartment building with her three-yearold daughter. Her seven-year-old daughter was also in the apartment at the time, asleep. Her husband, whom she was in the process of divorcing, had left home the previous evening.

On July 62015 I. F. (29) and her five-year-old son went missing. I.F left a note on her Facebook profile, directed primarily at her husband, in which she described the motives behind her decision to leave with their son. Three days later, their bodies and their car were found in a nearby lake. Drowning was determined as the cause of death.

On May 252017 C. P. R. (32), accompanied by her underage friend (14), suffocated her three-year-old son in their apartment. Following the murder, she left his body in a nearby cove, and then went to the police station to report him as missing, claiming that she didn't know what had happened to her child.

On October 10 2017, a car with the burnt bodies of M. Š. (29) and her two children, a five-year-old daughter and an 18-month-old son, were found in the woods near their hometown. The police investigation showed that their deaths were both filicide and suicide.

The coverage of these four cases in Croatian media and the general discourse surrounding them could be described as typical and expected - public outcries of horror, rage and shock were mixed with sensationalism and attempts of explaining the mothers' acts by professional experts, usually psychiatrists, whose analysis placed the acts of filicide firmly in the context of mental illness and/or the psychology of criminal behaviour. In addition, the 
cases were used to showcase the failings of the Croatian social welfare system, whose professionals were not able to recognise the pathological patterns of some of the mothers' behaviour. A more nuanced and detailed analysis of the issue of filicide in general and these cases in particular was largely absent from the mainstream media which was preoccupied by moral panic. As defined by Stanley Cohen, moral panic occurs when '[a] condition, episode, person or group of persons emerges to become defined as a threat to societal values and interests' (Cohen, 2004:1, quoted in Garland, 2008: 10), while 'its nature is presented in a stylized and stereotypical fashion by the mass media' (ibid.). David Garland identifies the mass media as

typically the prime movers and the primer beneficiaries of these episodes, since the sensation they create - a kind of collective effervescence - sells papers, entertains readers, and generates further news and commentary as the story unfolds, the spokesmen take sides, and the deviant phenomenon develops (Garland, 2008: 15).

Furthermore, 'successful moral panics owe their appeal to their ability to find points of resonance with wider anxieties' (Cohen, 2004: xxx, quoted in Garland, 2008: 12), which in these cases included the existing general distrust of the social welfare system structures (especially in C. P. R.'s case), and the traditional, 'common-sense' ideas about motherhood in Croatian society being seen as threatened by the deviant practices and 'transitions in the social, economic or moral order of the society' (Garland, 2008: 14). The aim of this paper is to look beyond sensationalism and superficial interpretations and to analyse it from the viewpoint of feminist theories of the ideology of motherhood and the practices of mothering in all their complexity.

The editorial and linguistic strategies used in the media coverage of the cases generally perpetuate the dominant ideology of motherhood in Croatian society are analysed in this article. For this purpose, selected journalism covering the cases published in Croatian mainstream news publications were read and compared; this included the digital editions of the national daily newspapers Jutarnji list, Večrnji list and 24sata, as the three publications with the largest circulation according to the results of the survey conducted by the National Competition Agency (Agencija za zaštitu tržišnog natjecanja) in $2017^{1}$. Minor websites which primarily reposted the articles from the bigger media outlets were also included, in order to demonstrate the uniformity in the approach to the stories.

Close textual reading of the discussions published on specialised Croatian online forums covering parenting issues contributes to a significant part of this paper. The focus is on the discussions devoted to perceived maternal failures and questioning of the unconditionality of maternal love, with the topic 'Nemajke' ('Non-Mothers') on forum.hr serving as the starting point. The real-life experiences shared online present a valuable addition to the theoretical discussion on rethinking and re-evaluating the ideas of motherhood, and help delineate the potential strategies for adopting a more nuanced approach to the multidimensional and often murky aspects of maternal love and mothering as caring, gendered labour.

\section{THE ABJECTION OF FILICIDE}

The current myth of motherhood, as American psychologist Shari Thurer points out, "holds that the well-being of our children depends almost entirely on the quality of their upbringing' (Thurer, 1995: xvi). Since the mother is usually the one providing for the physical, intellectual and emotional needs of the child, '[a]n intense, prolonged loving bond between mother and child is essential' (ibid.). The figure of mother is perceived as the one who must be always 'there' for her child, a safe harbour to which they can return even if/when everything else fails and everyone else betrays them, the one and only person who is expected to put others, not themselves, first. This is why the mother-child bond is considered to be something sacred, existing in a sphere separated from the corrupted, alienating, often crushing reality of the outside world. Furthermore, the ever-present idea of motherhood as a fixed biological essence attributed to women, accompanied by all the attributes of what 'good' motherhood should entail (which supposedly comes to women 'naturally'), makes the women who do not fit this essentialist criteria, suspicious.

If women are 'naturally mothers (...) born with a built-in set of capacities, dispositions, and desires to nurture children' (Hays, 1996), for whom, according to the best-selling parenting manuals (that function as the permeating expert narratives of the institutionalised ideology of motherhood), 'maternal love and affection are not only vital, they also come naturally' (Brazelton, 1983, quoted in Hays, 1996: 57), who are 'programmed with a whole set of "reflex" responses' (ibid.) that leave them 'geared to lavish affection on the child' (ibid.) due to the 'instinctive nature of mothering' (ibid.), the only explanation for the failure of individual women to fulfil these natural, pregiven roles is attributed to that of a horrible flaw in their very natures. Since 'it is women's "natural" role as mothers

\footnotetext{
1 Survey available at: http://www.aztn.hr/ea/wp-content/uploads/2016/10/Istra\%C5\%BEivanje-tr\%C5\%BEi\%C5\%A1ta-tiska-u2017.pdf
}

$2 / 17$

(C) 2019 by Author/s 
and carers that makes it so difficult for society to accept that women can harm children' (Jewkes, 2004: 123, quoted in Barnett, 2016: 13),

...the killing of a [new-born] child by its mother was wholly inconsistent with normally understood and expected maternal feelings and was generally regarded as a wholly unnatural offence. (Kilday, 2013: 16, quoted in Barnett, 2016: 58)

Thus, mothers who commit filicide are judged to have transgressed two sets of laws: criminal laws and the laws of nature' (Jewkes, 2004: 111, quoted in Barnett, 2016: 15).

The phenomenon of filicide, and the figure of the murdering mother, fit well into the Kristevian category of 'abjection' (Kristeva, 1982) - a seemingly impossible opposition of limitless mother-love and physical and emotional violence of murder result in an unbearable tension, the ultimate inability to understand the causes and motives of the act of filicide, which 'disturbs identity, system, order' (Kristeva, 1982: 4) since it is 'immoral, sinister, scheming, and shady: a terror that dissembles, a hatred that smiles' (ibid). The inability to understand the 'true' causes of a mother's decision to murder her child/ren is clearly visible in the language of the newspaper articles covering such cases. The question 'Why?' repeats itself over and over, in the form of a single desperate front page statement, or interwoven in the statements made by family members, acquaintances and neighbours. What is symptomatic for the language of the media, as well as the public discourse surrounding these cases in general, is the impossibility of closure, of providing straightforward answers. Even in cases such as that of I. F., who left an extensive note on her Facebook account (Trupeljak, 2015) ${ }^{2}$ detailing the reasons for her decision to end her own and her five-year-old son's life, an explanation eludes the public eye, as the trustworthiness of her words and point of view kept being questioned. Moreover, the mother's reasons fail to satisfy the public hunger for definitive answers; put simply, in filicide cases, no reason ever seems to be reason enough, which is why the notion of the monstrous mother functions as a short-term remedy for such public representations of trauma. Furthermore, in I. F.'s case, the very public nature of her detailed Facebook post in which she described occurrences of domestic violence and her loneliness and alienation, was contrasted with the testimonies of friends, acquaintances and neighbours whose contrasting narratives were filled with the combination of her smiles and their silence.

The reaction of the community in which this kind of traumatic killing occurs can then be perceived as a selfdefence mechanism: the idea that an individual - a mother - who can commit such an unspeakable act is actually not a person at all, but rather a monster mimicking human form, is far more acceptable than the notion that the idea of a mother who is supposed to selflessly love and fiercely protect, can be overturned in such a way as to become its own dark and twisted negative. Due to the pervading myths of motherhood and the female nature, the woman-as-mother is perceived as:

...beneficent, sacred, pure, asexual, nourishing; and the physical potential for motherhood - that same body with its bleedings and mysteries - is her single destiny and justification in life. (Rich, 1995: 27)

Since motherhood myths are embedded most human societies and taken for granted as commonsense and a natural truth, occurrences of maternal infanticide are perceived as particularly uncanny and disturbing. In Western European culture, historically the dichotomy between witches and mothers has utilised religious metaphor for the delineation of evil women, as has the idea of the 'monstrous feminine' (Creed, 2007). Invoking the monstrosity of a murdering mother is thus necessary for the sanity of the community. As Sarah LaChance Adams points out, in filicide cases 'we would prefer to think that such instances must be rare and pathological, the actions of deeply disturbed or evil individual' (Adams, 2014: 12), while Sarah Blaffer Hrdy states that since:

... killing one's own infant is so abhorrent to us (...) there is a tendency to compartmentalize the mother's actions as the intentional killing of her infant, and to consider her behaviour in isolation from her circumstances, even though they are functionally related. (Hrdy, 1999: 289-90)

The compartmentalisation can lead to a process of splitting or disidentification in which the 'conviction that the emotional ambivalence many mothers feel about investing in infants is 'unnatural', and hence very rare, and completely separate from more common, or 'normal', maternal emotions' (ibid).

Dehumanisation becomes necessary as a short-term coping mechanism; the problem is, however, this behaviour leads to the lack of a long-term analysis and deeper understanding of maternal filicide. The media presentation of the C. R. P.'s case is a good example of this type of dehumanization. Articles from different websites covering the case emphasised her perceived lack of emotion and regret during the trial, using the terms such as 'the mother from Hell' (ibid), and predicting that C.P.R. would claim insanity in order to avoid just punishment for her crime. As Barnett points out,

${ }^{2}$ Translations from Croatian into English were made by the author of the paper.

(C) 2019 by Author/s 
... outrage media offered a means for journalists and commentators to reinforce the good mother myth through the ironic argument that maternal infanticide is a crime so horrible that any mother who committed it must be insane, but, conversely, the argument that insanity is a fake defense. (Barnett, 2016: 207)

Contemporary media narratives continue to 'situate maternal violence as rare, unfathomable, and unpredictable' (Barnett, 2016: 2). This approach falls in line with what Barnett describes as 'the news media's shift in focus - from a public service to a profit-making industry' (ibid), which includes encouraging 'superficial coverage of maternal violence as reporters look for stories that sell, not stories that explain' (ibid). The delineation of 'mad' versus 'bad' mothers who commit infanticide further complicates the cultural representation of these women. In their book Mothers Who Kill Their Children: Understanding the Acts of Moms from Susan Smith to the Prom Mom', Michelle Oberman and Cheryl L. Meyer (2001) define the two categories in detail. According to the authors, 'mad' mothers are women who adhere to typical gender roles and the dominant social ideology of motherhood, so 'their crimes are considered irrational, incontrollable acts, usually the direct result of mental illness' (Oberman and Meyer, 2001: 69). On the other hand, 'bad' mothers are described as 'cold, callous, evil mothers who have often been neglectful of their children or their domestic responsibilities' (ibid, 70). The delineation of filicide-committing mothers is simplified through media and public discourse, resulting in what Williams (2017) defines as the 'nuts or sluts' argument, which also results in concrete legal consequences, since the 'mothers who are perceived as bad (...) receive harsher legal punishments' (Williams, 2017: 277).

Public opinion of mothers who kill their children is complexly interlinked with questions of class, race, and ethnicity, which are in turn deeply interwoven with the ideology of 'good motherhood' which in Croatia, as in Europe in general, is based on middle-class values and lifestyle. If the perpetrator adheres to the criteria of 'good motherhood' in her mothering practices prior to the filicide, this can shift her position in media representations of the story significantly. As Michelle Hughes Miller, Tamar Hager and Rebecca Jamremko Bromwich state in their introduction to Bad Mothers,

mothers of colour, mothers with disabilities, queer mothers, impoverished mothers, Aboriginal mothers - all these groups and many others have faced disapprobation not because of their actions as mothers but because of their identity and social status as mothers who do not fit the narrow racist, classist, gendered, ableist and heterosexist standards of idealized motherhood in Western Culture (2017: 16-17).

Since the mothers in question were all Caucasian and of Croatian ethnicity, racial and ethnic factors were not ephasized in the media coverage of the cases. That, of course, does not mean that race and ethnicity do not play a significant role in the establishment of the motherhood ideology in Croatia - for example, when assessing the quality of mothering and child upbringing of the Roma population (see, for example, Tomšić and Bakić-Tomić, 2015), or when mothers belong to ethnic minority groups, with special emphasis being on the Serbs, who constitute the largest ethnic minority group (according to the 2011 Croatian Census ${ }^{3}$ ) and can be considered as the most significant ethnic minority in Croatia, due to complex historical and political reasons (see, for example, Babić, 2015).

Unlike C. P. R., the three other mothers were married; in cases of I. F. and M. Š., the testimonies of their family members, friends and acquaintances repeatedly positioned them as devoted, caring mothers. On the other hand, the media coverage of C.P.R.'s case focused heavily on her 'deviant' sexual history and enterprises; moreover, her intention to get rid of her child in order to be able to pursue a new romantic/sexual relationship was emphasised in media narrative as the main motive for her act. The delineation between the two categories of representation was prominent in the media representation of the cases of I. F. and C.P.R.. ${ }^{4}$ The online and newspaper articles covering I. F.'s case were mostly accompanied by the photographs of I. F. with her son, both of them smiling (Jutarnji.hr, 2015; 24sata.hr, 2015) ${ }^{5}$; in contrast, articles dealing with C. P. R.'s case use more provocative

\footnotetext{
3 Available at: https://www.dzs.hr/Hrv_Eng/publication/2011/SI-1441.pdf

${ }^{4}$ Most of the images used to accompany the stories, both in print and electronic media, were taken from the social media profiles of I. F. and C. P. R. Since I find this practice, very common in Croatian media, ethically questionable, I have chosen not to include these images in this article, because I feel that by doing so I would reproduce their exploitation.

5 See Figure 1 at https://www.24sata.hr/news/prijatelji-ivane-fogadic-29-smijehom-je-skrivala-strah-427731 and Figure 2 at https://www.jutarnji.hr/vijesti/crna-kronika/cijelo-medimurje-traga-za-ivanom-i-patrikom-muz-u-cudu-stvarno-ne-znam-zasto-je-otislasve-je-bilo-normalno.../278713/.
} 
photographs from social media (Istarski.hr, 2017; Jutarnji.hr, 2018) ${ }^{6}$ or photographs showing her being taken into custody or to court, accompanied by headers implicating her inhumanity (Vě̌rrnji.hr, 2018). ${ }^{7}$

\section{THE PERFECT MOTHER AND THE IDEOLOGY OF INTENSIVE MOTHERHOOD}

In The Cultural Contradiction of Motherhood, Sharon Hays describes the contemporary model of motherhood in Western society as 'intensive motherhood' (Hays, 1996), whilst in Judith Warner and Joan Wolf use the term of 'total motherhood' (Warner, 2006: 52; Wolf, 2011: 71). Hays describes labour intensive motherhood as a gendered model which requires an immense amount of time, energy and money spent on child-upbringing (Hays, 1996). This model positions the mother as the primary caretaker concentrated on fulfilling each and every need of the child, with 'methods prescribed by experts, which are demanding and expensive' (Hays, 1996: 21). The focal point of Hays's analysis is the ideological opposition of the public, rational sphere of work and business and the private, emotionally charged sphere of family and motherhood; this dichotomy positions motherhood as opposed to economy and politics, which is why it is perceived 'as something that stems from love or altruism and thus does not require any reward' (Glenn, 1994: 16); this reinforces the assumption that 'mothers should be completely selfabnegating' (ibid).

The mother-as-an-individual is thus rather seen through the lens of the mother-as-an-ideal; the role of mother diminishes all other roles that a woman can assume, as well as the woman's own subjectivity. This sterotype can be widely observed throughout Western culture and institutions. Motherhood seems to erase all other personal traits of an individual, effectively turning her into an embodied symbol. As Adams states, this kind of 'romanticization of mothering can be difficult to resist' (Adams, 2014: 25), since:

...motherhood carries heavy symbolism and mothering/being mothered is a significant formative experience for most people. (ibid)

The perceived sacredness of motherhood demands a specific set of traits from an individual mother; on the other hand, the lack of such traits leads to condemnation. These expectations can present a suffocating burden for mothers who may be convinced by societal norms that anything less than total abnegation of their needs is unacceptable, leading to the undoing of their subjectivity. As Adams argues, 'in many respects, the birth of the child is the death of the mother as she has known herself (Adams, 2014: 92).

Popular parenting manuals may function as the main sources of the parenting ideology, with this discourse being further appropriated and reinforced by other media sources, as well as the word of mouth. The 'expert' discourse in self-help manuals further cements the role of the mother as the primary caretaker whose duty is to respond primarily to the requirements and challenges of child-rearing and care. In the Western world, expert narratives function as 'authoritative knowledge' (Jordan, 1997, quoted in Miller, 2005: 29), that 'will shape individuals' expectations and experiences [regarding pregnancy, childbirth and mothering] and ultimately how sense is made of them' (ibid). Thus forms of 'cultural scripts' (ibid) which are 'socially constructed, historically specific and culturally varied' (Miller, 2005: 28) create an ideology of intensive motherhood and shape the 'context in which women become mothers' (Miller, 2005: 62). However, this scripted expert knowledge is neither unambiguous nor necessarily empowering. Due to multiple, often clashing expert narratives existing in the public space, it is often extremely difficult, if not impossible, to determine the 'right' parenting technique, which can result in additional maternal insecurity and anxiety. Even though the contemporary manuals, with Sears and his 'attachment parenting' ideology being the prime example, insist on returning to 'natural' motherhood, the very prescriptiveness of the expert discourse undermines the narrative of motherhood as intuitive and instinctive, so 'motherhood becomes a calling that demands skill training, professional development, systematicity and selfscrutiny' (Vidmar Horvat, 2017: 113). Faced with demands and prescriptions, many mothers 'try to achieve Sears' ideal of nursing, baby wearing and co-sleeping but fall short for some reason and find themselves immobilized by their seeming parental inadequacy' (Pickert, 2012). Thus, exposure to the scripted expert discourse does not automatically equal with the increase in the perceived maternal competence nor the personal feeling of adequacy.

Parenting manuals authored by these experts originating from the USA, Great Britain and the Scandinavian countries can be positioned as the official expert narrative on child rearing and care in Croatia as well. This is the

\footnotetext{
${ }^{6}$ See Figure 3 at https:/ / istarski.hr/node/42249-trazila-muskarce-na-internetu-i-bila-nabijena-seksualnim-strastima (the headline is 'Tražila muškarce na internetu i bila nabijena seksualnim strastima' ['She was looking for men online and was longing for sexual activity']) and Figure 4 at https:/ /www.jutarnji.hr/vijesti/hrvatska/ne-pokazuje-zaljenje-zamjera-si-samo-jednu-stvar-je-li-sustav-zakazao-kod-najmladedjevojcice-u-hrvatskoj-osumnjicenoj-za-tesko-ubojstvo/7197438/ (the headline, 'Ne pokazuje žaljenje, zamjera si samo jednu stvar' ['She's not showing any remorse, she resents only one thing'], is misleading, since it actually does not refer to C. P. R., but to her fourteen-year-old accomplice).

${ }^{7}$ See Figure 5 at https://www.vecernji.hr/vijesti/danas-presuda-majci-koja-je-ugusila-dijete-1240211. The headline is 'C. P. nije pokazala nimalo emocija ni kajanja' ['C. P. hasn't shown any emotions or remorse'].
} 
result of globalisation processes and the saturation of the media and public discourse in general by the ideas and values shared by the western cultural patterns, which are accepted largely uncritically and transposed onto Croatian society. Books by influential authors like Benjamin Spock (1946), T. Berry Brazelton (2004, 2003, 2002, 2001, 1993), Penelope Leach $(1994,1978)$, and Williams Sears $(2005,2004,2001,1995,1993)$ are translated into Croatian and available in bookstores and public libraries. ${ }^{8}$ Magazines and websites catering to parents perpetuate dominant parenting ideologies. As authors like Judith Warner point put, the media play a huge role in 'prescribing and proscribing norms for maternal behaviour' (Warner, 2006: 4), by 'contrasting what they deem to be the socially acceptable "good" mother with what they believe to be the reprehensible "bad" mother' (ibid). Moreover, ideas about parenting in general and motherhood and mothering in particular are affirmed and perpetuated on specialised online discussion boards covering child rearing-related issues. In the Croatian online media, there are two major sites for digital discussion: on roda.br, specialising in parenting issues, and the sub-topic 'Parents and Children' under the forum. $h r$, the largest Croatian discussion board covering a variety of general topics. It is important to point out that roda.br is the official web page of the Roda organisation (standing for Roditelji u akcijiParents In Action), an influential promoter of attachment-style parenting values. Roda participates in different types of actions and activities that aim to influence parenting in general, as well as its concrete aspects, from state provision, such as the legislation and practices in maternity hospitals (for example, the recent 'Prekinimo šutnju' 'Break the Silence' campaign (Prekinimo šutnju, 2018)), to interventions in the private sphere of individual decisions and everyday practices, such as breastfeeding, baby hygiene, sleeping arrangements, and so on.

The role of these specialised discussion boards is two-fold. First, they play a supportive and advisory role that used to be reserved for family members, especially other, more experienced female members of the family, like grandmothers, aunts and older sisters who could provide new mothers with practical advice, as well as emotional support. The increased physical mobility of families connected with the modern lifestyle very often means that the extended family members are living far away from new mothers, who can then turn to a virtual community through discussion boards, with more experienced mothers giving advice to new mothers. Furthermore, discussion boards can also function as a supportive group of friends who share their experiences, show understanding for the various difficulties that motherhood entails and help each other to weather out the daily stress, fears and isolation characteristic of the initial period in the lives of new mothers.

Authors like Barbara Barnett attribute only positive aspects to motherhood blogs and discussion boards, claiming that they "demonstrate an "ethic of care" (Petersen, 2014: 289, quoted in Barnett, 2016: 256), as women are focused on social responsibility and positive ideas and ideals. However, it is questionable whether all the discourse that occurs on the discussion forums and blogs necessarily maintains this affirmative tone. As mentioned earlier, the virtual community is also the place where the dominant parenting/mothering ideology is affirmed and perpetuated. Shared personal practices and experiences can thus be judged by other discussion participants, depending on how much the individual mother adheres to / deviates from the dominant ideology. In this way, forum discussions cannot only be seen as the 'safe space' for mothers, but also as a supervising and correctional tool.

Since 'forum.hr is the leading Croatian forum portal with over 430,000 listed members (www.forum.hr; March 2016)' (Miljković Krečar and Kolega, 2017: 516), with 1594 topics currently listed in the sub-forum 'Parents and children' / 'Roditelji i djeca' (last access 10 July 2019), it was chosen as the analysis material. Close reading of the aforementioned sub-forum was conducted from April 2018 to November 2018. It included overview of all listed topics, after which particular threads of interest were chosen, based on their titles and potential connection with the issues of maternal ambivalence, clashes with the dominant motherhood ideology or other specific difficulties and challenges that mothers face in their everyday practices. Of the topics singled out in this way, four are included in this paper: 'Nemajke' / 'Non-Mothers' (first post 27 March 2010, last post 11 October 2017, total number of posts 6734, available at http:/ /www.forum.hr/showthread.php?t=536100, last accessed 6 July 2019), 'Jeste li ikada viknuli na svoje dijete?' / 'Have you ever yelled at your baby?' (first post 3 November 2011, last post 19 December 2011, total number of posts 64, available at http:/ /www.forum.hr/ showthread.php? $\mathrm{t}=683337$, last accessed 7 July 2019), 'Postporođajna depresija' / 'Postpartum Depression' (first post 22 January 2004, last post 17 June 2019, total number of posts 348, available at http://www.forum.hr/showthread.php?t=311015, last accessed 7 July 2019), 'Želim da nikad nisam imala dijete, je li to normalno?' / 'I wish I'd never had a child, is that normal?' (first post 28 November 2015, last post 12 February 2016, total number of posts 220, available at http://www.forum.hr/showthread.php?t=914086, last accessed 10 July 2019). The purpose of the close reading of the forum posts was to find and analyse potential clashes of individual maternal practices with the dominant motherhood ideology and the reactions of other discussion participants to these maternal transgressions.

\footnotetext{
${ }^{8}$ Some of the titles translated into Croatian have multiple editions. First editions in English are included in the reference list, followed by all the Croatian editions currently listed in the Croatian public library catalogues.
} 


\section{WHAT MAKES A 'NON-MOTHER'}

One of the ways of dealing with feelings of inadequacy on these sites is through humour and strategies of what Marijana Hameršak identifies as 'affirmative parenting manuals' (Hameršak, 2009: 19), which includes the texts which are 'aimed at meeting, or failing to meet, expectations and requirements which are the result of putting the pieces of advice from the first category of manuals (the so-called prescriptive manuals) into practice', their focus being on 'survival strategies' (Hameršak, 2009: 19). Hameršak notes that the affirmative manuals do not present 'the needs of mothers, their retreats and frustrations' as pathological, and their tone is usually 'cordial, friendly (...) and often humorous' (Hameršak, 2009: 19). Hameršak includes different literary genres in this category, from more classic forms of parenting manuals, through memoires to even chick-lit. ${ }^{9}$ With the advent of blogs and forums specialized for detailing the daily minutiae of maternal experiences, this type of affirmative manual narrative has also moved to the digital sphere, where (anonymous) mothers share and discuss their perceived 'failures' in the 'cordial, friendly (...) and often humorous' tone that Hameršak recognizes as the significant trait of this type of discourse.

The topic 'Nemajke' / 'Non-Mothers' on forum.hr (available at http://www.forum.hr/ showthread.php?t $=536100$ ) is an example of this type of humorous confessional narrative, in which posters list their imperfections and failures in a sort of tongue-in-cheek subversion of the ideology of intensive motherhood:

I see that on this discussion board a lot of attention is being given to stating who is a better mother, whose child will be bigger, stronger, whose baby food will be healthier, whose house cleaner, whose clothes will be ironed better, etc. This is why I invite you to write why you belong in the infamous category of non-mothers (nemajke), that is, what are some things that you did that ideal mothers would never do (for whichever reason)? (Anonymous_1, 27 March 2010, post number 1)

The topic thread includes maternal 'failures' and 'transgressions' in various, generally heavily proscribed, areas of mothering, for example, preparing nutritious, healthy meals: 'My kid had chocolate and juice for breakfast this morning' (Anonymous_2, 22 May 2010, post number 992); participating in outdoor activities: 'I'm so glad it was raining today so we didn't have to go out for a walk. I really didn't feel like it.' (Anonymous_3, 1 October 2010, post number 2387); daily routine:

I've taught them to make their own breakfast, to turn on the cartoons by themselves, to use everything with buttons, to brush their teeth, to clean their room... All that for purely selfish reasons, just so I can sleep a bit longer in the morning (especially if I'm working in the afternoon).

And sometimes I make grilled sandwiches and pizza for lunch, sometimes just sunny-side-up eggs and I don't care :-

They also play Playstation and watch cartoons much more than they should.

And I've even taught the older one how to find assigned reading essays online (I really love technology) (:) (Anonymous_4, 28 March 2010, post number 17);

and strategies for finding some time for oneself:

The other day I had to take my baby's poo sample to hospital for testing, and she stayed at home with my husband. On my way back, I bought Story [a popular Croatian women's celebrity and fashion magazine] and sat in the car in the parking lot and read it because I knew I wouldn't be able to do that at home.

And my husband called me two times to see why it's taking so long, I didn't hear my mobile phone, and later I told him that there was a traffic jam.

(Anonymous_5, 12 October 2012, post number 4790)

\footnotetext{
${ }^{9}$ The term was originally (and ironically) coined by Chris Mazza for the edited anthology Chick Lit: Postfeminist Fiction (1995), but it evolved and „worked its way through academic and conservative criticism, and into popular culture”(Farkas, 2006: 902), with Helen Fielding's Bridget Jones's Diary (1997) being labelled as the prime example. Chick lit 'deals with the intimate experience of women negotiating identities and cultural expectations on the level of the everyday' (Farkas, 2006: 902) reflecting 'the anxieties of today's "transitional" women, who take certain rights for granted while still feeling much stress and ambivalence about identity, sexual agency, and the attractions or perils of work, marriage, and motherhood' (ibid., 903).
} 
The experiences shared in the thread mainly concern benign everyday imperfections - giving children too much candy or letting them watch a couple of cartoons more than deemed appropriate. When these 'deviations' are mentioned, participants very often emphasise that this is not their usual norm - these are exceptions, small slippages that occur when they are experiencing an especially difficult day. However, even in this 'humorous' context, participants are informed that they are not conforming to the expected maternal behaviour that fits the requirements of the dominant ideology of motherhood. The idea of abstaining from judgement proves to be impossible, with various posters calling out the discussion participants on their perceived bad mothering practices, with maternal selfishness being pointed out as the main objection:

some of you are truly horrible. but $i$ think that probably the worst is the one who wrote: instead of a feeding chair for the baby i bought a pair of jeans for myself. I hate selfish parents. (Anonymous_6, 31 March 2010, post number 281)

I've been reading this thread for the last couple of days and I'm at a loss for words, you really are nonmothers.... I don't see what's so funny about letting children cry while you put your mp3 headphones on so you can't hear their about their needs, they must be crying because they feel like it, right, and it hasn't crossed your minds that by crying they are letting you know about their needs.... (...)

You add tons of fabric softener to the laundry that your children wear on their sensitive skin - read a bit about the fabric softener ingredients instead of bragging about the shameful things you do here.

Breastfeeding + smoking + beer $=$ horror

I won't even comment on other things because the things you do are making me sick and you are bragging about it because it's supposed to be funny and cute. (Anonymous_7, 3 May 2010, post number 773)

You console one another on this thread because you've realised that it's not easy to be a mum, that it's normal to be sleep deprived after you give birth, that your baby is the centre of your world and that EVERYTHING revolves around them not YOU (...)

Yeah, it's not easy to be a mum but some of us are at least trying. (Anonymous_ 7, 3 May 2010, post number 813)

You can say whatever you want but i really see no reasons why a 5-6-month-old child (and maybe even younger, i don't know when you began doing this) should be left to sleep somewhere else, even if it's at their grandparents'. A child that old needs their mom (and dad) the most. (Anonymous_ 8 December 2010, post number 2883)

The humorous tone can also function as mimicry for other, more sinister feelings which are still deemed unacceptable to express in the public sphere. Shari Thurer points out that 'maternal altruism is difficult to sustain' (Thurer, 1995: xvi):

While our children fill us with cosmic joy (...) they also provoke in us at times such anger and frustration that we hardly recognize the fury as our own. If motherhood is the dreamy relationship it is often billed as, then those flashes of hostility must be unnatural, traitorous, destructive of all that is normal, good and decent. The resulting self-doubt is not much talked about. Mothers may joke about it, but they do not talk about it seriously. (ibid)

However, even in the 'serious' context of sharing experiences, in which participants express their need for advice and emotional support, the deeply embedded notions of good and bad mothering and mothers are reasserted. For example, when a participant notes that she sometimes yells at her children 'Jeste li ikada viknuli na svoje dijete?' / 'Have you ever yelled at your baby?', available at http:/ /www.forum.hr/showthread.php?t=683337) and that she feels guilty because of that ('I definitely feel like the worst mother in the world...' - Anonymous_9, 3 November 2011, post number 1), and the other one notes that this behaviour is normal and that it will leave no permanent negative consequences on the children, other commentators are quick to remind her of the accepted approaches to child development and psychology:

You can't tell this for sure, and I sincerely doubt that this won't leave any consequences. It depends on what you mean by 'consequences'. When we yell at children, they are scared, they feel insecure and sad, and it can affect their self-confidence, their view of themselves and others, and, as far as I'm concerned, 
even if it only applies to that isolated act of yelling and the short period of time afterwards, it's not something that you should consider to be of no importance whatsoever. (Anonymous_10, 3 November 2011, post number 8)

Furthermore, even in the 'humorous' thread like the 'Non-Mothers', the initial purpose of which is subverting the norms of the dominant motherhood ideology, some of the participants self-diagnose their behaviour as pathological, even when concrete examples of 'non-mothering' practices are absent from their narrative, like in the case of the participant whose maternal failures stem from her perceived inability to comply with the ideal of perpetually happy, totally committed mother:

Guys, I feel like a non-mother for days now. I take care of my little son all day long, the best way I know and can. I take care of him on my own, my husband works all day, nobody has changed his diaper since the day he was born but me. Sometimes I'm tired, sleepy and tense, maybe I don't play with him enough, sometimes I sing to him, but not always. I feel bad because I'm not a happy, smiling mother all the time, at least while he is still so little.

At the end of the day when he falls asleep, like now, I watch the photos I took of him and I feel like crying... My little one, my little munchkin who depends only on me and I'm the most important thing to him, and I often surf the internet or watch TV while I'm breastfeeding him, I'm not focused completely on him.

Does this make me a non-mother? (Anonymous_ 11 July 2010, post number 1208)

The idea of permanently happy and content mother is present even in the topic dealing with serious mental health conditions which can significantly affect individual maternal experiences. In the discussion string dealing with postpartum depression ('Postporođajna depresija' / 'Postpartum Depression', available at http://www.forum.hr/showthread.php?t=311015), participants generally presented their attitudes as understanding and non-judgemental, emphasising how difficult the consequences of this condition can be if it remains untreated. However, some of the posts claimed that they 'did not have the time' to suffer from postpartum depression on account of the health problems they themselves or their babies experienced after birth. In this way, postpartum depression is minimalised and implied to be a personal 'failure':

I didn't suffer from that. My baby had a bad case of neonatal jaundice and was kept in the hospital, I was too worried and obsessed with milk pumping to have the time for baby blues (Anonymous_12, 22 January, 2004, post number 4).

I've heard that this [postpartum depression] exists, but I have never experienced it myself, well, since I literally fought for survival during my baby's childhood, so being depressed afterwards was the last thing on my mind, just joy and the wish to recover as soon as possible (Anonymous_13, 23 January, 2004, post number 9).

I didn't feel depressed immediately after giving birth; I think I had less time in general so I just didn't have time to think about myself (Anonymous_14, 19 December, 2006, post number 167).

In the testimonies of mothers in infanticide cases that Barnett (2016) covers in her book, in many instances women saw themselves as failed mothers. This was usually combined with substance abuse and/or a long history of mental problems. Since the still prevailing ideology of our society claims that 'women have one pathway to fulfilment - child care' (Almond, 2010, quoted in Barnett, 2016: 17), good mothers seemingly are 'never aggressive or apathetic, and they certainly are never depressed' (ibid). The unattainable ideal of intensive motherhood stigmatises mental illness and can lead to devastating consequences if mothers are too ashamed or scared to ask for help, if even available. As Caplan points out,

...when women believe they are bad mothers, their self-esteem plummets, their sense of isolation grows, and the likelihood they will abuse their children increases. (Caplan, 2010, quoted in Barnett, 2016: 59)

Ann Oakley points out that maternal depression can often be directly linked to the expectation that motherhood requires abnegation of the self' (quoted in Adams, 2014: 42). If a mother finds it difficult to comply with the requirement of total selflessness, this can be judged as a deep personal flaw or unwillingness to shake off the selfish and self-involved mindset of her pre-maternal state.

As the subjects of the interviews included in Hays's book unanimously point out, a bad mother is 'a mother who neglects her kids for selfish reasons, because she is more concerned with her personal fulfilment, her leisure 
pursuits, her material possessions, and her status than she is with her children' (ibid), while 'the very definition of good mothering includes the willingness to give up things so that your children can have things' (ibid, 126). In the Croatian filicide cases, this moral failure of selfishness is seen as brought to its ultimate outcome: 'Women who kill their children are selfish if they cannot put their children's interests ahead of their own' (Barnett, 2016: 148). This selfishness is especially severely condemned if it is perceived as stemming from the mother's sexuality: the long association of motherhood with purity and asexuality makes the topic of mothers' sexuality distasteful per se; if it is viewed as a motivating factor for the abuse, neglect and filicide, it enters the field of unthinkable. In the media coverage:

... the women's sexual history became a topic in news stories, and while promiscuity does not equal violence, it was included in news stories as evidence that [the mothers who committed filicide] were not only abusive; they were irresponsible and immoral. (Barnett, 2016: 135)

Brief historical overviews of the practice of filicide world-wide, by Hrdy (1999) and Barnett (2016), show that in certain cultures and/or periods in human history filicide was widespread for religious or social reasons, including a 'brutal act of mercy' (Barnett, 2016: 56). Mothers who commit filicide are prone to describing their acts as merciful and necessary, especially if the murder of the child is accompanied by the mother's suicide. For example Keira V. Williams (2018) presents two cases from the 19th century, those of Margaret Garner and Hester Vaughan, in which the mothers' decision to end their children's lives resulted from dire circumstances of slavery and poverty. In her Facebook post, similarly, I. F. wrote that she is taking her son with her because she wants to save him from a miserable childhood with his father (Trupeljak, 2015).

Filicide may be seen as the ultimate act of care and good mothering, the final ethical imperative (Adams, 2014). Guilt can also have a role in filicide, when failing to meet the unattainable standard of ideal motherhood:

When mothers think they should be able to give to their children infinitely and are unable to do so (as no human could), they feel guilty, angry, worthless, ashamed, depressed, and fearful of judgment of others. These feelings paralyze mind and body, making it difficult to respond to one's child at all, let alone appropriately. (Adams, 2014: 92)

In the preface to Bad Mothers, Miller et al. lists types of bad mothering - abuse and neglect, abandonment of children, immoral conducts, emotional and psychological violence, and, 'in its most extreme form (...) infanticide' (Miller et al., 2017: 5). These types of failures are socially perceived 'to be in [bad mothers'] maternal actions (or inactions) and in their identities, for which they alone are responsible' (ibid), while attention is rarely paid 'to the context within which women mother or the structures that constrain their mothering choices' (Griffin, quoted in Miller et al., 2017: 5). In a heteronormative society it is noted that fathers rarely, if ever, face the same quality criteria for their parenting practices - the phenomenon of the 'invisible father' is present 'in intensive motherhood due to the perceived status of motherhood and the financial security provided by their partner in a heteronormative context' (Ames, 2017: 23). Similarly, in filicide cases, which 'focuses on the mother and tends to neglect the dynamic between the couple' and 'the father appears to be an unimportant factor in understanding the mother's condition' (Wheelwright, 2002: 273). Maternal filicide can also be perceived as an act of revenge against the husband/father, but a subtler analysis of his role is usually missing from media representation of the act.

Just as motherhood, in Adrienne Rich's words, is earned through everyday nurturing practices of mothering which are never finalised (Rich, 1995), but continue to establish and re-establish the child-mother relationship on a daily basis, 'bad mothering' (sometimes simultaneously) undergoes the same process, used as a sign of warning, a constant reminder that the 'good mother' status is never permanent and always under close scrutiny, both internal and external, and how slipping into the dreaded category of an inadequate, harmful, monstrous mother is perhaps an easy fate. Since ' $\mathrm{f}$ ] or mothers, perfection is the expectation, not the exception' (Barnett, 2016: 81), even the routine practices of feeding or cleaning the child can be scrutinised, and the

...spectre of the bad mother who fails to contend with risk appropriately is a critical mode of social control, for she is an internalized figure that serves as a point of comparison for mothers to assess the quality of their own mothering. (Malacrida, 116, quoted in Campbell, 2017: 147-8)

Moreover, once gained, the bad mother status is not something that can be easily nullified, so the return to good mothering is a much more difficult task than the other way around. This does not come as a surprise since, in the expert discourse which functions as surveillance, the long-term effects of bad mothering are construed as having effects well into future generations' (Campbell, 2017: 136). The prescriptiveness of the official discourse of good motherhood leads to interventions in the individual mothers' lives, aimed at regulating the practices defined as deviant: 
The regulatory discourses of medical workers, family members, friends, and even strangers encourage continual self-appraisal and discipline not only because women internalize the narratives of good mothering but also because they want to elude being viewed as a reviled figure. (Campbell, 2017: 148)

The Perfect Mother myth and the ideal of intensive motherhood have proven to be so pervading and overpowering that they persist even in the contexts of the filicide cases. Barnett notes that

.. in the analysis of the news stories (...), although she was never mentioned, the Perfect Mother was the standard by which all women were measured and by which women measured themselves (...) And while women who killed their children acknowledged they failed to properly care for their children, they also stated that perfection was what they strived for. (Barnett, 2016: 102)

The correlation between the symbolic ideal and filicide can be viewed as twofold. First, as Geraldine Holloway points out in her empirical study of maternal filicide, a number of authors consider 'the social construction of motherhood to be a significant aspect of filicide' (Holloway, 2016: 116), referring to the works of Morris and Wilczynski (1993), Alder and Baker (1997) and Alder and Polk (2001) who,

...consider these idealised stereotypes of woman and mothers alongside an alternative construction which they term the 'dark side of motherhood' in which the burden of responsibility for child-rearing falls disproportionately upon mothers. (Holloway, 2016: 117)

The expectations laid by the perfect motherhood ideology may result in 'good mother stress' that Mugavin (2005, quoted in Holloway, 2017: 116)) positions as 'one of the triggers to maternal filicide' (ibid.), which is 'related to the pressure of trying to be a good mother, although lacking sufficient validation for the role' (ibid.) Furthermore, essentialist approaches to motherhood may lead to cognitive dissonance, in the questioning of their 'true femininity' (Oakley, 1981, quoted in Holloway, 2017: 116) in women who struggleto experience 'natural' maternal instincts and whose feelings toward their children and their maternal role are more complicated and/or ambivalent.

Secondly, the idea of 'altruistic filicide' (Resnick, 1969) can be perceived to be closely related to the intensive motherhood ideology which positions the mother as the primary caretaker and beneficiary for the well-being of her children. In her study, Holloway introduces a number of factors listed as the possible catalysts or triggers for filicide. Her study subjects express feelings of social isolation, suspiciousness aimed at social services and society in general and anxiety about the possibility of being separated from their children, as well as prominent suicidal thoughts. In this context, '[m]others are conceptualised as having killed their children either to save them from being motherless and/or to protect them from perceived harm' (Holloway, 2016: 127), with their decision being 'modulated by simultaneous beliefs about both Saving and Uniting with their child' (ibid.). In this light, filicide is viewed as what has controversially been described as a 'mercy killing'; it is stated as one of the five major motives in Resnick's review of psychiatric literature on this topic: 'a mother kills her child out of love' (Friedman and Resnick, 2007: 137) since 'she believes death to be in the child's best interest' (ibid.). As studies by Somander and Ramen and Friedman et al. show, the motive of filicide was "usually considered to be "altruistic", in the sense that the well-being of the child was of primary concern' (quoted in Willemsen et al., 2007: 2016) and that 'the mothers were motivated by the desire to alleviate real or imagined suffering in their children' (ibid.). Since the main postulates of perfect mothering are maternal selflessness and acting in what is perceived to be the best interest of the child, the mother perceives her suicide as 'an unacceptable abandonment of the child' (Holloway, 2016: 127), while simultaneously 'the killing of the child is a way of ensuring that the child was safe from perceived harm' (ibid.). As I. F. expressed in her suicide note, 'My only happiness didn't deserve any of this, but he is still making this journey with me, but only to the point where our paths part... He will be much better off there!' (Direktno.hr, 2015). The final lines in her tragic letter paint the picture of her son as an angel playing and laughing from the clouds above. I. F. points out that she will not be joining him in his new home (their paths parting after their deaths), so the logical conclusion is that, if her son becomes an angel in heaven, she is doomed to spend the eternity in hell. This religious symbolism serves as further proof of her perceived selflessness - suffering torment for all eternity is the sacrifice she is willing to take on in order to prevent her son from facing 'an intolerable world' Friedman and Resnick, 2007: 137) or to save him 'from a fate worse than death' (ibid.).

\section{CONCLUSION: MOTHERHOOD AND/AS AMBIVALENCE}

Feminist approaches to understanding filicide have multiple approaches to deal with. It seems both logical and tempting to perceive the mothers who commit filicide as the victims of 'the invisible violence of the institution of motherhood, the guilt, the powerless responsibility for human lives, the judgments and condemnations, the fear 
of her own power, the guilt, the guilt, the guilt' (Rich, 1995: 276), and to claim that 'every mother exists on the spectrum within danger of killing their children and that spectrum is created by the conditions of patriarchal motherhood' (Ames, 2017: 30). However, this approach risks falling 'into an essentialist trap (..), which frequently takes refuge in ideas of fixed female or maternal self' (Jeremiah, 2004: 60) by 'suggesting that mothering is actually and essentially loving' (ibid), thus simplifying the variety of emotions experienced in the mother-child relationship, and coming full circle to the western conventional position of the natural female's preconditioning towards nurturing and motherhood. Furthermore, it simplifies the positions of what are perceived as 'good' and 'bad' mothers, by claiming that:

...women who actually act in accordance with the myth (of good motherhood) are privileged because of the ways this ideology sustains power structures, but (they) are also considered to be passive recipients of normative power. (Rozmarin, 2018: 352)

Since such women are thus 'victims of self-annihilating practices' (ibid), they are not perceived to be politically useful in the dismantling of the patriarchal institution of motherhood, unlike the 'bad mothers' who resist and undermine its containments.

In order to avoid a simplification of the 'good' and 'bad' mother dichotomy, it is necessary to try to accomplish the integration of the political and the ethical while rethinking motherhood as a possible resource for a new understanding of subjectivity. This implies understanding the ethics of care of others in a broader sense that encompasses both the political and moral aspects of different facets and choices of mothering, as well as applying moral imagination to care practices of mothering within the institution of motherhood through a specific kind of 'maternal thinking' (Ruddick, 1995). The final story in this paper can function as an example of how this dichotomy can be bridged, and how a more nuanced perception of the ethics of care can influence the way we approach motherhood and mothering.

In a post entitled 'Želim da nikad nisam imala dijete, je li to normalno?' / 'I wish I'd never had a child, is that normal?' (available at http://www.forum.hr/showthread.php?t=914086), a mother I will call Anonymous_15 writes that, even though she has a happy family, a loving husband and a son whom she loves more than anything in the world (and would, if necessary, sacrifice her life for without hesitation), she regrets becoming a mother, claiming that, if she could go back in time and do everything all over again, she would not give birth to him. Anonymous_15 finishes her story with a question/plea: "Is there anybody else who feels this way or am I truly a monster?" (Anonymous_15, 5 December, 2015, post number 43). A number of discussion participants expressed suspicion about the sincerity of the author's love for her child, as well as reservations about the quality of maternal care she is able to provide, deeming that the hate Anonymous_15 expresses towards her maternal role and mothering practices are incompatible with feelings of 'genuine' maternal love. Their conclusions chiefly concur with Anonymous_15's perceived selfishness, in accordance with dominant values which imply 'that our children are exquisitely delicate creatures, hugely vulnerable to our idiosyncrasies and deficits, who require relentless psychological attunement and approval' (Thurer, 1995: xiii):

Children are happy only if they have happy parents. The poster's child is definitely not happy, we shouldn't fool ourselves. Children are not things. They have feelings (Anonymous_, 16, 7 December, 2015, post number 75).

The child didn't ask to be born, didn't choose their mother or deserved to be unhappy... and the child is unhappy and you are going to maim their ability to build their future, establish relationships and become a parent.

You thing you perform your role well? You think your child doesn't feel this and that this will never surface and leave deep scars on all three of you? (Anonymous_17, 7 December 2015, post number 79).

And please don't tell me you really love that child so much. That's not true, you love yourself and you miss the life you had before the child (Anonymous_18, 11 December 2015, post number 110).

It wasn't the right time for you to have a child and you viewed everything through your selfish interests to fulfil the society's expectations and you weren't ready to be a parent... Now suffer your punishment, you can blame only yourself not the child whose life you are ruining... (Anonymous_19, 17 December 2015, post number 140, available at)

The main point of conflict in Anonymous_15's case is thus the perceived incompatibility between the appropriate mothering and child-rearing (and, consequently, a well-socialized, psychologically healthy child) and the lack of enjoyment in the everyday practices of motherhood and the maternal role as such. This brings us back 
to the idea of motherhood as fundamentally interwoven with the feelings of love, devotion and pleasure - the thought (and example) of a mother who experiences these two spheres as separate is perceived as disturbing and unnatural, the popular conclusion is that Anonymous_15 is a 'non-mother'. However, Adrienne Rich declares that 'motherhood is earned, first through an intense physical and psychic rite of passage - pregnancy and childbirth then through learning to nurture, which does not come by instinct' (Rich, 1995: 10), thus making motherhood a permanent process which needs to be updated, re-learnt and re-established on a daily basis. The connective tissue of this process consists of different types of care practices that the mother implements in her daily interactions with the child. As Rich states:

We learn, often through painful self-discipline and self-cauterization, those qualities which are supposed to be 'innate' in us: patience, self-sacrifice, the willingness to repeat endlessly the small, routine chores of socializing a human being. (Rich, 1995: 31)

Becoming adequate in the mothering practices and in the socialization processes does not have to equal enjoyment in the process; even if/when a mother cares, she can also simultaneously mourn the loss of her past personhood and personal freedom; even when she sacrifices, it does not necessarily come without the feelings of grief, resentment or even remorse. As Sara Ahmed claims,

[b]ecoming caring is not about becoming good or nice (...) To care is not about letting an object go but holding on to an object by letting oneself go, giving oneself over to something that is not one's own. (Ahmed, 2010: 186)

In addition,

[c] aring is anxious - to be full of care, to be careful, is to take care of things by becoming anxious about their future, where the future is embodied in the fragility of an object whose persistence matters. (ibid)

In her posts Anonymous_15 expresses deep anxiety about the safety and health of her child, as well as personal resignation that there is a quick (or basically any) solution or an escape route to her ambivalence. 'From the way you make things sound, it seems that you will be unhappy for the rest of your life. And that's that. Right?', (Anonymous_20, 5 December 2015, post number 54) asks one of the commentators, and Anonymous_15's response is 'More or less, yes' (Anonymous_15, 6 December 2015, post number 55). Anonymous_15 is thus not looking for a solution on the discussion board, she is looking for psychological support and empathy, which is found to be lacking in general, since only two of the discussion contributors recognised the subject Anonymous_15 had raised as generally important for the perception/misconceptions that surround the institution of motherhood and its contemporary ideology.

It is impossible to determine the exact causes of maternal filicide - shame, mental illness, poverty, social stigma and isolation are just some of the factors that affect the state in which a mother tries to mother, and fails. The role of the mother figure in traditional ideology is one of the primary caretaker who loves unconditionally and is always prepared to sacrifice herself for her child(ren). Since motherhood is perceived as 'natural' for women, negative feelings of depression, discontent and anger are not deemed compatible with this perception - on the contrary, they are viewed as unnatural and deviant, even monstrous. For some authors, 'a mother does not need extraordinary circumstances to kill her children' (Ames, 2017: 6), since the impossible standards of the contemporary ideology of motherhood make even the 'ordinary experience of motherhood (...) extraordinary enough' (ibid). Challenging the concepts of maternal perfection and perfect mothering can be the first step in the right direction.

\section{REFERENCES}

24sata (2018). Žalba odbačena: Majci iz pakla 33 godine za ubojstvo sina (3) [Complaint denied: Mother from hell sentenced to 33 years for murdering her son] - article, 24sata, 25 September. Available at: https:/ /www.24sata.hr /news/vrhovni-sud-odbacio-zalbu-33-godine-za-ubojstvo-malog-sina-591913 (Accessed 10 October 2018).

Adams, S. L. (2014). Mad Mothers, Bad Mothers and What a "Good" Mother Would Do - The Ethics of Ambivalence. New York: Columbia University Press (ebook edition).

Ahmed, S. (2010). The Promise of Happiness. Durham and London: Duke University Press. https://doi.org/10.1215/9780822392781

Ames, K. M. (2017). Murdering Mothers? Representations of Mothers Who Kill Their Children in Theatre and Law. Master thesis, Graduate Program in Interdisciplinary Studies, York University, Toronto. Available at: 
https://yorkspace.library.yorku.ca/xmlui/bitstream/handle/10315/33550/Ames_Kaley_M_2017_Masters.p df? sequence $=2 \&$ is Allowed $=\mathrm{y}$ (Accessed 10 November 2018).

Anonymous_1 (2010). Nemajke [Non-Mothers] - discussion board posts, forum.hr, 27 March 2010, post number 1. Available at: http:/ / www.forum.hr/showthread.php?t=536100 (Accessed 6 July 2019).

Anonymous_10 (2011). Jeste li ikada viknuli na svoje dijete? [Have you ever yelled at your baby?] - discussion board posts, forum.hr, 3 November, post number 8 . Available at: http:/ / www.forum.hr/showthread.php?t=683337 (Accessed 7 July 2019).

Anonymous_11 (2010). Nemajke [Non-Mothers] - discussion board posts, forum.hr, 11 July, post number 1208. Available at: http:/ /www.forum.hr/showthread.php?t=536100\&page=61 (Accessed 6 July 2019).

Anonymous_12 (2004). Postporođajna depresija [Postpartum Depression] - discussion board posts, forum.hr, 22 January, post number 4. Available at: http://www.forum.hr/showthread.php?t=311015 (Accessed 7 July 2019).

Anonymous_13 (2004). Postporođajna depresija [Postpartum Depression] - discussion board posts, forum.hr, 23 January, post number 9. Available at: http://www.forum.hr/ showthread.php?t=311015 (Accessed 7 July 2019 ).

Anonymous_14 (2006). Postporođajna depresija [Postpartum Depression] - discussion board posts, forum.hr, 19 December, post number 9. Available at: http:/ / www. forum.hr/ showthread.php? $\mathrm{t}=311015$ \&page $=9$ (Accessed 7 July 2019).

Anonymous_15 (2015a). Želim da nikad nisam imala dijete, je li to normalno? [I wish I'd never had a child, is that normal?] - discussion board posts, forum.hr, 5 December, post number 43. Available at: http:/ / www.forum.hr/showthread.php?t=914086\&page=3 (Accessed 10 July 2019).

Anonymous_15 (2015b). Želim da nikad nisam imala dijete, je li to normalno? [I wish I'd never had a child, is that normal?] - discussion board posts, forum.hr, 6 December, post number 55. http:/ / www.forum.hr/showthread.php?t=914086\&page=3 (Accessed 7 July 2019).

Anonymous_16 (2015). Želim da nikad nisam imala dijete, je li to normalno? [I wish I'd never had a child, is that normal?] - discussion board posts, forum.hr, 7 December, post number 75 . Available at: http:/ / www.forum.hr/showthread.php?t=914086\&page=4 (Accessed 10 July 2019).

Anonymous_17 (2015). Želim da nikad nisam imala dijete, je li to normalno? [I wish I'd never had a child, is that normal?] - discussion board posts, forum.hr, 7 December, post number 79. Available at: http:/ / www.forum.hr/showthread.php?t=914086\&page=4 (Accessed 10 July 2019).

Anonymous_18 (2015). Želim da nikad nisam imala dijete, je li to normalno? [I wish I'd never had a child, is that normal?] - discussion board posts, forum.hr, 11 December, post number 110. Available at: http:/ / www.forum.hr/ showthread.php?t=914086\&page=6 (Accessed 10 July 2019).

Anonymous_19 (2015). Želim da nikad nisam imala dijete, je li to normalno? [I wish I'd never had a child, is that normal?] - discussion board posts, forum.hr, 17 December, post number 140. Available at: http:/ / www.forum.hr/showthread.php?t=914086\&page=7 (Accessed 10 July 2019).

Anonymous_2 (2010). Nemajke [Non-Mothers] - discussion board posts, forum.hr, 22 May, post number 992. Available at: http:/ / www.forum.hr/showthread.php?t=536100\&page=50 (Accessed 6 July 2019).

Anonymous_20 (2015). Želim da nikad nisam imala dijete, je li to normalno? [I wish I'd never had a child, is that normal?] - discussion board posts, forum.hr, 5 December, post number 55 . Available at: http:/ / www.forum.hr/showthread.php?t=914086\&page=3 (Accessed 10 July 2019).

Anonymous_3 (2010). Nemajke [Non-Mothers] - discussion board posts, forum.hr, 1 October, post number 2387. Available at: http:/ /www.forum.hr/showthread.php?t=536100\&page=120 (Accessed 6 July 2019).

Anonymous_4 (2010). Nemajke [Non-Mothers] - discussion board posts, forum.hr, 28 March, post number 17. Available at: http:/ / www.forum.hr/showthread.php?t=536100 (Accessed 6 July 2019).

Anonymous_5 (2012). Nemajke [Non-Mothers] - discussion board posts, forum.hr, 15 October, post number 4790. Available at: http://www.forum.hr/showthread.php?t=536100\&page=240 (Accessed 6 July 2019).

Anonymous_6 (2010). Nemajke [Non-Mothers] - discussion board posts, forum.hr, 31 March, post number 281. Available at: http:/ / www.forum.hr/showthread.php?t=536100\&page=15 (Accessed 6 July 2019).

Anonymous_7 (2010a). Nemajke [Non-Mothers] - discussion board posts, forum.hr, 3 May, post number 773. Available at: http://www.forum.hr/showthread.php?t=536100\&page=39 (Accessed 6 July 2019).

Anonymous_7 (2010b). Nemajke [Non-Mothers] - discussion board posts, forum.hr, 3 May, post number 813. Available at: http://www.forum.hr/showthread.php?t=536100\&page=41 (Accessed 6 July 2019).

Anonymous_8 (2010). Nemajke [Non-Mothers] - discussion board posts, forum.hr, 8 December, post number 2883. Available at: http:/ / www.forum.hr/showthread.php?t=536100\&page=145 (Accessed 6 July 2019).

Anonymous_9 (2011). Jeste li ikada viknuli na svoje dijete? [Have you ever yelled at your baby?] - discussion board posts, forum.hr, 3 November, post number 1. Available at: http://www.forum.hr/showthread.php?t=683337 (Accessed 7 July 2019).

Babić, D. (2015). Nacionalne manjine u Hrvatskoj: sociološka perspektiva. [National Minorities in Croatia: A Sociological Perspective]. Zagreb: Plejada. 
Barnett, B. (2016). Motherhood in the Media: Infanticide, Journalism, and the Digital Age. New York and London: Routledge (ebook edition).

Brazelton, T. B. and Sparrow, J. D. (1993). Touchpoints - Birth to Three. Cambridge: Da Capo Press Lifelong Books. $[(2009,2007,2004,2000)$. Vaše dijete : važni dogadaji u osjécajnom, tjelesnom i društvenom ražoju. Zagreb: Mozaik knjiga.]

Brazelton, T. B. and Sparrow, J. D. (2001). Touchpoints - Three to Six. Cambridge: Da Capo Press Lifelong Books. [(2007, 2005). Vaše dijete : od tré́e godine do škole : razvoj emocija i ponašanja. Zagreb: Mozaik knjiga.]

Brazelton, T. B. and Sparrow, J. D. (2002). Sleep - The Brazelton Way. Cambridge: Da Capo Press Lifelong Books. [(2006). Spavanje: Brazeltonov pristup. Lekenik: Ostvarenje.]

Brazelton, T. B. and Sparrow, J. D. (2003a). Calming Your Fussy Baby - The Brazelton Way. Cambridge: Da Capo Press Lifelong Books. [(2006). Uplakana beba: Brazeltonov pristup. Buševec: Ostvarenje.]

Brazelton, T. B. and Sparrow, J. D. (2003b). Discipline - The Brazelton Way. Cambridge: Da Capo Press Lifelong Books. [(2008). Disciplina : Brazeltonov pristup. Buševec: Ostvarenje.]

Brazelton, T. B. and Sparrow, J. D. (2003c). Toilet Training - The Brazelton Way. Cambridge: Da Capo Press Lifelong Books. [(2006). Odvikavanje od pelena: Brazeltonov pristup. Lekenik: Ostvarenje.]

Brazelton, T. B. and Sparrow, J. D. (2004). Feeding Your Child - The Brazelton Way. Cambridge: Da Capo Press Lifelong Books. [(2007). Hranjenje bebe i djeteta: Brazeltonov pristup. Lekenik: Ostvarenje.]

Campbell, A. (2017). The Risky Mother: The Medicalization of Mothering, in M. H. Miller, T. Hager and R. J. Bromwich (eds), Bad Mothers: Regulations, Representations and Resistance (pp. 132-157). Bradford: Demeter Press (ebook edition).

Creed, B. (2007). The Monstrous-Feminine. Film, Feminism, Psychoanalysis. London \& New York: Routledge.

Direktno.hr (2015). Cijela poruka nestale Ivane: Kurvao si se, ušla sam ti u poruke i FB [The full text of missing Ivana's letter: You were whoring around, I hacked your messages and your FB account] - article, Direktno.hr, 7 May. Available at: https://direktno.hr/direkt/cijela-poruka-nestale-ivane-kurvao-si-se-usla-sam-ti-u-porukei-fb-18863/ (Accessed 4 February 2019).

Direktno.hr (2017). Majka ubijenog dječačića bila je nabijena seksualnim strastima [The mother of the murdered boy was longing for sexual activity] - article, Direktno.hr, 26 May. Available at: https://direktno.hr/direkt/majka-ubijenog-djecacica-bila-je-nabijena-seksualnim-strastima-86910/ (Accessed 9 October 2018).

Farkas, C. (2006). Chick-Lit. The New Woman's Fiction. The Journal of Popular Culture, 39(5), 902-903. https://doi.org/10.1111/j.1540-5931.2006.00314.x

Friedman, S. Hatters and Resnick, P. J. (2007). Child Murder by Mothers: Patterns and Prevention. World Psychiatry 2007; 6, 137-141. Available at: https://www.researchgate.net/publication/5663192_Child_Murder_by_ Mothers_Patterns_and_Prevention (Accessed 1 February 2019).

Garland, D. (2008). On the concept of moral panic. Crime, Media, Culture: An International Journal, 4(1), 9-30. https://doi.org/10.1177/1741659007087270

Glenn, E. N. (1994). Social Constructions of Mothering: A Thematic Overview, in E. N. Glenn, G. Chang and L. R. Forcey (eds), Mothering: Ideology, Experience, and Agency (pp. 1-29). New York and London: Routledge. https://doi.org/10.4324/9781315538891-1

Hameršak, M. (2009). Majčinstvo i savjetnici: Od Mulihova Posæla apostolsækog do Budiæma za majke [Moterhood and Parenting Books: from Mulih's Poszao apostolski to Buddhism for Mothers. Tré́a 1, vol. XI, 9-24.

Hays, S. (1996). The Cultural Contradictions of Motherhood. New Haven and London: Yale University Press.

Holloway, G. (2016). Maternal Filicide: Grounded Theorising from Interviews with Mothers with a Diagnosis of Mental Illness. A thesis submitted for the degree of Professional Doctorate School of Health and Human Sciences University of Essex. Available at: http://repository.essex.ac.uk/17667/1/GT\%20THESIS\%20ENDNOTE\%20 STRIPPED\%20FINAL.pdf (Accessed 1 February 2019).

Hrdy, S. B. (1999). Mother Nature: Maternal Instincts and How They Shape the Human Species. New York - Toronto: The Ballantine Publishing Group. https://doi.org/10.1038/18979

Istarski.hr (2017). Tražila muškarce na internetu i bila nabijena seksualnim strastima [She was looking for men online and was longing for sexual activity] - article, Istarski.hr, 26 May. Available at: https://istarski.hr/node/42249-trazila-muskarce-na-internetu-i-bila-nabijena-seksualnim-strastima (Accessed 9 October 2018).

Jeremiah, E. (2004). Murderous Mothers: Adrienne Rich's Of Woman Born and Toni Morrison's Beloved, in A. O’Reilly (ed), From Motherhood to Mothering: The Legacy of Adrienne Rich's Of Woman Born (pp. 59-71). New York: State University of New York Press.

Karakaš Jakubin, H. (2017). Tražila muškarce na internetu i bila nabijena seksualnim strastima [The mother who killed Denis (3) was luring men online: 'She was longing for sexual activity, she said she was living alone and she didn't mention her son.'] - article, Jutarnji.hr, 25 May. Available at: https://www.jutarnji.hr/vijesti/crna- 
kronika/majka-koja-je-ubila-denisa-3-nudila-se-muskarcima-na-internetu-bila-je-nabijena-seksualnim-strastim a-rekla-je-da-zivi-sama-sina-nije-spominjala/6129541/ (Accessed 9 October 2018).

Kristeva, J. (1982). Powers of Horror. New York: Columbia University Press.

Leach, P. (1978). Your Baby and Child: From Birth to Age Five. New York: A. A. Knopf. [(2009, 2007, 2004). Vaše dijete: novo izdanje za novu generaciju. Zagreb: Algoritam; (1989, 1987, 1984, 1979). Odgoj i njega djeteta. Zagreb: Mladost.]

Leach, P. (1994). Children First: What Our Society Must Do - and is Not Doing - for Our Children. New York: Vintage Books. [(2003). Prvo djeca: što društvo ne čini, a trebalo bi, za današnju djecu. Algoritam: Zagreb.]

Mazza, C., DeShell J. and Sheffield, E. (1995) Chick Lit: Postfeminist Fiction. Carbondale: FC2.

McCullough, K. Of Woman (but Not Man or the Nuclear Family) Born: Motherhood Outside Institutionalized Heterosexuality, in A. O'Reilly (ed), From Motherhood to Mothering: The Legacy of Adrienne Rich's Of Woman Born (pp. 103-124). New York: State University of New York Press.

Miller, M. H., Hager, T. and Bromwich, R. J. (2017). The Bad Mother, in Relief, in M. H. Miller, T. Hager and R. J. Bromwich (eds), Bad Mothers: Regulations, Representations and Resistance (pp. 1-20). Bradford: Demeter Press (ebook edition).

Miller, T. (2005). Making Sense of Motherhood - A Narrative Approach. New York: Cambridge University Press. https://doi.org/10.1017/CBO9780511489501

Miljković Krečar, I. and Kolega, M. (2017). Analysis of Superposters’ Motives for Participating in Online Forum Discussions. Psibologijske teme, 26(2017), 3, 509-531. https://doi.org/10.31820/pt.26.3.2

Oberman, M. and Meyer, C. L. (2001). Mothers Who Kill Their Children: Understanding the Acts of Moms from Susan Smith to the 'Prom Mom'. New York: New York University Press.

Pickert, K. (2012). The Man Who Remade Motherhood. TIME Health. Available at: https://time.com/606/theman-who-remade-motherhood/ (Accessed 1 July 2019).

Popis stanovništva 2011. [Census 2011] (2011). Available at: https://www.dzs.hr/Hrv_Eng/publication/2011/SI1441.pdf (Accessed 6 July 2019).

Prekinimo šutnju [Break the Silence] (2018). Available at: https://www.prekinimosutnju.hr/ (Accessed 8 October 2018).

Rich, A. (1995). Of Woman Born: Motherhood as Experience and Ideology. New York and London: W. W. Norton \& Company.

Rozmarin, M. (2017). Medea Chic: On the Necessity of Ethics as Part of the Critique of Motherhood, in M. H. Miller, T. Hager and R. J. Bromwich (eds), Bad Mothers: Regulations, Representations and Resistance (pp. 344-361). Bradford: Demeter Press (ebook edition).

Ruddick, S. (1995). Maternal Thinking: Towards a Politics of Peace. Boston: Beacon Press.

Sears, W. and Sears, M. (1993). The Baby Book - Everything You Need to Know about Your Baby From Birth to Age Two. New York, Boston \& London: Little, Brown and Company. [(2016, 2010). Njega djeteta : od rodenja do druge godine života. Zagreb: Mozaik knjiga.]

Sears, W. and Sears, M. (1995). The Discipline Book. New York, Boston \& London: Little, Brown and Company. [(2016, 2009). Disciplina : kako postići da se dijete bolje ponaša od rođenja do desete godine. Zagreb: Mozaik knjiga.]

Sears, W. and Sears, M. (2001). The Attachment Parenting Book: A Commonsense Guide to Understanding and Nurturing Your Baby. Boston, New York \& London: Little, Brown and Company. [(2009, 2008). Povezujuće roditeljstvo : priručnik za razumijevanje i odgoj vašeg djeteta. Zagreb: Mozaik knjiga]

Sears, W., Sears, M., Sears, R. and Sears, J. (2004). The Premature Baby Book: Everything You Need to Know About Your Premature Baby from Birth to Age One. New York \& Boston: Little, Brown and Company. [(2014). Njega i zdravlje nedonošcadi : sve što je potrebno znati o prijevremeno rođenoj djeci od rodenja do prve godine. Zagreb: Mozaik knjiga.]

Sears, W., Sears, M., Sears, R. and Sears, J. (2005). The Baby Sleep Book: The Complete Guide to a Good Night's Rest for the Whole Family. New York, Boston \& London: Little, Brown and Company. [(2015). Kako uspavati dijete : sve što trebate znati kako biste lakše uspavali dijete i cijeloj obitelji omogućili zdrav razum i okrepljujući san. Zagreb: Mozaik knjiga.]

Spock, B. (1946). The Common Sense Book of Baby and Child Care. New York: Duell, Sloan and Pearce. [(2004) Dr. Spock - Odgoj i njega djeteta. Botteri i sinovi: Split; (1994) Dr. Spock - Njega i odgoj djeteta. Zagreb: SysPrint; (1987) Nega odojčadi i podizanje dece. Beograd: Rad; (1974) Kako njegovati i odgajati dijete. Zagreb: Stvarnost; (1964). Sto treba znati o odgoju djeteta. Zagreb: Stvarnost; $(1961,1958)$. Sto treba znati o odgoju djeteta. Zagreb: Novinarsko poduzeće.]

Špac, L. (2015). Cijelo Međimurje traga za Ivanom i Patrikom [Whole Međimurje is searching for Ivana and Patrik] - article, Jutarnji list, 7 July. Available at: https://www.jutarnji.hr/vijesti/crna-kronika/cijelo-medimurje-tragaza-ivanom-i-patrikom-muz-u-cudu-stvarno-ne-znam-zasto-je-otisla-sve-je-bilo-normalno.../278713/

(Accessed 9 October 2018).

Thurer, S. (1995). The Myths of Motherhood: How Culture Reinvents the Good Mother. New York: Penguin Books. 
Tkalčević, H., Rukavina, Ž. (2015). Prijatelji Ivane Fogadić (29): 'Smijehom je skrivala strah...' [Friends of Ivana Fogadić (29): 'She was hiding her fears behind her smile'] - article, 24sata, 11 July. Available at: https://www.24sata.hr/news/prijatelji-ivane-fogadic-29-smijehom-je-skrivala-strah-427731 (Accessed 10 October 2018)

Tomšić, M. and Bakić-Tomić, Lj. (2015). The Perception of the Public about the Roma Minority in the Field Medimurje County. Media, Culture, and Public Relations 6, 2015, 2, 172-180. Available at: https://hrcak.srce.hr/index.php?show=clanak\&id_clanak_jezik=219383 (Accessed 29 June 2019).

Trupeljak, K. (2015). Majka ostavila oproštajnu poruku i nestala sa sinom... [Mother left a goodbye note and went missing with her son] - article, vijesti.rtl.hr, 6 July. Available at: https://vijesti.rtl.hr/novosti/hrvatska/ 1675450/majka-nestala-sa-sinom-i-ostavila-oprostajnu-poruku-na-facebooku-nemojte-zaliti-za-mnom/ (Accessed 9 October 2018).

Turčin, K. (2018). Ne pokazuje žaljenje, zamjera si samo jednu stvar [She's not showing any remorse, she resents only one thing'] - article, Jutarnji.hr, April, 3. Available at: https://www.jutarnji.hr/vijesti/hrvatska/nepokazuje-zaljenje-zamjera-si-samo-jednu-stvar-je-li-sustav-zakazao-kod-najmlade-djevojcice-u-hrvatskojosumnjicenoj-za-tesko-ubojstvo/7197438/ (Accessed 20 June 2019).

Večernji list / Hina (2018). Chiara Pašić nije pokazala nimalo emocija ni kajanja [Chiara Pašić hasn’t shown any emotions or remorse] - article, Večernji.hr, April 20. Available at: https://www.vecernji.hr/vijesti/danaspresuda-majci-koja-je-ugusila-dijete-1240211 (Accessed 30 June 2019).

Vidmar Horvat, K. (2017). Imaginarna majka. Rod i nacionalizam u kulturi 20. stoljéca. Zagreb: Sandorf.

Warner, J. (2006). Perfect Madness: Motherhood in the Age of Anexiety. New York: Riverhead Books.

Wheelwright, J. (2002). Nothing in Between: Modern Cases of Infanticide, in Mark Jackson (ed), Historical Perspectives on Child Murder and Concealment (pp. 1550-2000). London: Routledge.

Willemsen, J., Declerq, F., Markey, S. and Verhaeghe, P. (2007). The Role of Affect Regulation in a Case of Attempted Maternal Filicide-Suicide. Clinical Social Work Journal, 34(4), 215-221. Available at: https://www.academia.edu/11388009/The_Role_of_Affect_Regulation_in_a_Case_of_Attempted_Maternal _Filicide_Suicide (Accessed 3 February 2019).

Williams, K. V. (2017). Feminism, Infanticide, and Intersectionality in Victorian America, in M. H. Miller, T. Hager and R. J. Bromwich (eds), Bad Mothers: Regulations, Representations and Resistance (pp. 277-296). Bradford: Demeter Press.

Wolf, J. (2011). Is Breast Best? Taking on the Breastfeeding Experts and the New High Stakes of Motherhood. New York and London: New York University Press. https:// doi.org/10.18574/nyu/9780814794814.001.0001

Citation: Tomić, B. P. (2019). "How Could a Mother Do That to Her Children?": Filicide and Maternal Ambivalence in Croatian Media and Online Discourse. Feminist Encounters: A Journal of Critical Studies in Culture and Politics, 3(1-2), 15. https://doi.org/10.20897/femenc/5921 